\title{
PKM PENDAMPINGAN DAN PENYULUHAN KERAJINAN LIMBAH KREATIF PADA PEMULUNG DI TPA BANTAR GEBANG BEKASI
}

\author{
Purwani Puji Utami $^{*}$, Devita Cahyani Nugraheny ${ }^{2}$, Niken Vioreza ${ }^{3}$, Arbiana Putri ${ }^{4}$ \\ ${ }^{1}$ STKIP Kusuma Negara, Jakarta, Indonesia \\ *Email: purwani_puji@stkipkusumanegara.ac.id
}

\begin{abstract}
Informasi Artikel Abstrak
Kata kunci :

pemberdayaan

pemulung;

kewirausahaan; limbah,

kerajinan tangan.

Diterima: 12-05-2021

Disetujui: 10-06-2021

Dipubikasikan: 16-07-

2021

Kegiatan Pengabdian Kepada Masyarakat (PKM) ini dalam rangka mendukung upaya pengentasan kemiskinan melalui pendekatan pemberdayaan para pemulung, di kelurahan Sumur Batu, kecamatan Bantar Gebang, kota Bekasi. Tujuan utama dari kegiatan PKM adalah menumbuhkembangkan usaha mikro bagi para pemulung, yang kesehariannya bekerja di TPA dan belum tersentuh ketrampilan kewirausahaan. Solusi dan metode pada program PKM ini dengan memberikan pendampingan, penyuluhan serta pelatihan ketrampilan kepada para pemulung sesuai kondisi mitra serta limbah yang dimiliki pada wilayahnya, hingga mampu menghasilkan produk unggulan bernilai ekonomis serta dibutuhkan oleh pasar. Pelatihan yang diberikan juga akan mencakup teknis produksi, desain produk, branding kemasan produk serta pemasaran berbasis Internet of Things (IoT) yang sangat sesuai dengan promosi produk di masa pandemic Covid-19. Kepada mitra pemulung diberikan pula penyuluhan motivasi kewirausahaan dan pelatihan ketrampilan manajerial kewirausahaan, yang di dalamnya mencakup manajemen produksi, manajemen keuangan, akuntansi sederhana dan manajemen pemasaran. Selain itu, dilakukan pendampingan kepada mitra, agar upaya menumbuh kembangkan kegiatan usaha mikro pada para pemulung dapat terwujud dan berjalan dengan baik. Luaran dari kegiatan pengabdian ini adalah: (1) terbentuknya usaha mikro yang mampu memberikan penghasilan tambahan kepada pemulung, dan (2) terciptanya produk barang hasil produksi pemulung yang layak dipasarkan.
\end{abstract}

Abstract
Keywords :

waste empowerment;

entrepreneurship; waste recycling, handicraft.

picker
This PKM's program is in order to support efforts to alleviate poverty through the empowerment approach of waste pickers, in Sumur Batu subdistrict, Bantar Gebang district, in Bekasi city. The main objective of this activity is to develop micro businesses for waste pickers, who work at the TPA on a daily basis and have not yet touched entrepreneurial skills. Solutions and methods in this PKM's program are by providing assistance, counseling, and skills training to waste pickers, according to the conditions of the partners and the waste that they have in their areas, to able to produce high value economic products and needed by the market. This training provided included technical production, product design, branding and packaging, and also marketing based Internet of Things (IoT) which is very 
suitable for product promotion during the Covid-19 pandemic. Waste picker partners also get entrepreneurial motivation and counseling which includes production management, financial management, simple accounting and marketing management. Besides that, partners also get business assistence to develop their micro-business activities for waste pickers. Hope their business can be run well. The outputs of this PKM's programs are: (1) the micro-businesses which created to provide additional income to waste pickers, and (2) partners can be produce a marketable products.

\section{PENDAHULUAN}

Perencanaan pembangunan yang teruji, holistik, dan berkesinambungan akan bermakna jika kelompok masyarakat dalam triple helix, yaitu akademisi, dunia usaha, dan pemerintah dapat bersinergi secara utuh. Bidang usaha, peran sektor Usaha Mikro, Kecil dan Menengah (UMKM) di berbagai negara sudah tidak dapar diragukan lagi. Di Indonesia, UMKM sebagai pilar ekonomi nasional. Beberapa masyarakat memanfaatkan UMKM untuk meningkatkan kesejahteraan ekonomi mereka. Hal ini terbukti bahwa sektor UMKM dapat bertahan dalam situasi krisis ekonomi. Beberapa peran penting usaha kecil di Indonesia antara lain: 1) usaha kecil merupakan pemain utama kegiatan ekonomi Indonesia, 2) penyedia kesempatan kerja, 3) pemain penting dalam pengembangan ekonomi lokal dan pengembangan masyarakat, 4) pencipta pasar dan inovasi melalui fleksibilitas dan sensitivitasnya yang dinamis serta keterkaitannya dengan beberapa perusahaan, 5) memberikan kontribusi terhadap peningkatan ekspor non migas (Utami et al., 2019). Peran tersebut dapat didukung dengan keterampilan pengusaha dalam meningkatkan kinerja usahanya.

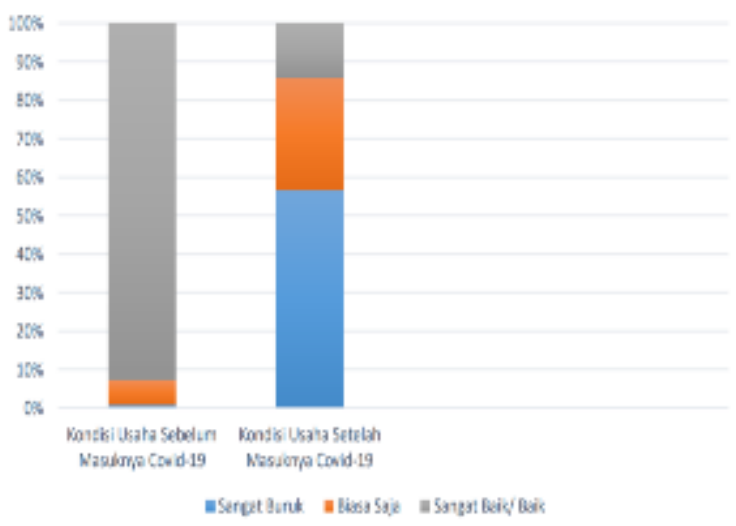

Gambar 1. Perbandingan Kondisi Usaha Sebelum dan Saat Terdampak Covid-19 Sumber: Badan Pusat Statistik-data diolah (Soleha, 2020)

Berdasarkan gambar di atas terdapat perbandingan yang sangat signifikan mengenai kondisi usaha sebelum dan saat terdampak covid-19 secara umum. Menurut penilaian pemaparan dalam grafik menyatakan bahwa kondisi sebelum covid-19 persentase kondisi usaha baik/sangat baik sebesar 92,7 persen, persentase kondisi usaha biasa saja sebesar 6,3 persen, dan kondisi usaha buruk/sangat buruk sebesar 1,0 persen. Dalam persentase sebelum masuknya covid-19 dinilai berjalan dengan lancar, tidak banyak kendala, dan minimnya kondisi buruk dalam usaha. Namun jika melihat kondisi usaha 
saat ini (per Juni 2020) menurut survei yang telah dipaparkan dalam grafik bahwasanya kondisi usaha buruk/sangat buruk meningkat sebesar 56,8 persen dibanding yang semulanya hanya sebesar 1,0 persen. Kondisi usaha biasa saja juga meningkat sebesar 29,1 persen dari yang semulanya hanya 6,3 persen. Selain itu, kondisi usaha baik/sangat baik menurun, yang semula 92,7 persen menjadi 14,1 persen.

Pertumbuhan UMKM di Indonesia sangat tinggi sebelum pandemi Covid-19. Hal ini dapat dilihat pada Gambar 1. Berdasarkan gambar 1 terdapat perbandingan yang sangat signifikan mengenai kondisi usaha sebelum dan saat terdampak covid-19 secara umum. Menurut penilaian pemaparan dalam grafik menyatakan bahwa kondisi sebelum covid-19 persentase kondisi usaha baik/sangat baik sebesar 92,7 persen, persentase kondisi usaha biasa saja sebesar 6,3 persen, dan kondisi usaha buruk/sangat buruk sebesar 1,0 persen. Dalam persentase sebelum masuknya covid-19 dinilai berjalan dengan lancar, tidak banyak kendala, dan minimnya kondisi buruk dalam usaha. Namun jika melihat kondisi usaha saat ini (per Juni 2020) menurut survei yang telah dipaparkan dalam grafik bahwasanya kondisi usaha buruk/sangat buruk meningkat sebesar 56,8 persen dibanding yang semulanya hanya sebesar 1,0 persen. Kondisi usaha biasa saja juga meningkat sebesar 29,1 persen dari yang semulanya hanya 6,3 persen. Selain itu, kondisi usaha baik/sangat baik menurun, yang semula 92,7 persen menjadi 14,1 persen.

Dengan demikian dapat disimpulkan bahwa perkembangan UMKM di Indonesia sebelum pandemi Covid-19 terus meningkat dari tahun ke tahun, hal tersebut yang menjadikan pemerintah Indonesia harus terus mendukung UMKM dengan memberikan bantuan baik dari segi modal maupun keterampilan pengusahanya. UMKM menyumbang 60,34\% (persen) dari total Produk Domestik Bruto (PDB) nasional dan menyumbang 58,18\% (persen) dari total investasi. Namun, UMKM juga menjadi kelompok yang rentan di tengah situasi pandemi Covid-19. Tak sedikit UMKM gulung tikar akibat badai ini. Misalnya saja, warung-warung kecil yang terpaksa tutup karena sepi pembeli. Kamar Dagang dan Industri Indonesia (Kadin) mengonfirmasi dari 64.200.000 UMKM yang ada di Indonesia, sekitar 50\% (persen) atau setara 30.000.000 UMKM harus tutup sementara akibat pandemi Covid-19. Bahkan, berdasarkan data Lembaga Ilmu Pengetahuan Indonesia (LIPI), bila pandemi tak kunjung usai, 85,42 persen UMKM yang tidak berinovasi melalui pemasaran digital hanya akan mampu bertahan selama satu tahun (Farhanah, 2020).

Berdasarkan data dari Kementerian Koperasi dan UMKM, hingga saat ini dari total 64.000.000 pelaku UMKM, baru sekitar 8.000 .000 atau 13\% yang sudah terhubungan dengan dunia digital. Padahal, transaksi di dunia digital terus meningkat, terutama di masa pandemi ini, ketika pergerakan masyarakat mulai dibatasi. Dari data McKinsey yang disampaikan oleh Menteri Koperasi dan UMKM Teten Masduki, sejak awal pandemi hingga Juni 2020 telah terjadi kenaikan penjualan melalui platform dagang-online sebesar 26\% sehingga total transaksi mencapai 3.100 .000 per hari. Angka ini menunjukkan peluang yang besar bagi jutaan UMKM di Indonesia untuk memperluas jangkauan melalui digitalisasi. Namun, untuk mendukung percepatan transformasi digital para pelaku UMKM, 
dibutuhkan peran serta dari berbagai pihak, tidak cukup hanya pemerintah sendiri tetapi juga perlu dukungan dari pihak swasta dan masyarakat (Andriani, 2020).

UMKM ini ternyata juga bisa dikembangkan pada limbah yang oleh kebanyakan masyarakat dianggap tidak berguna, dengan menggunakan sedikit inovasi mengubah limbah menjadi barang unik dan bernilai ekonomis melalui pemasaran berbasis Internet of Things (IoT). Selama ini kita mengetahui bahwa Tempat Pengelolaan Sampah Terpadu (TPST) berada di Bantar Gebang yang merupakan salah satu kecamatan di kota Bekasi, Provinsi Jawa Barat. Kecamatan ini terbagi menjadi 4 kelurahan, meliputi: Kelurahan Bantargebang 406,244 Ha; Kelurahan Cikiwul 525,351 Ha; Kelurahan Ciketing Udik 568,955 Ha; Kelurahan Sumur Batu 343,340 Ha.

UMKM merupakan usaha yang menghasilkan produk untuk di jual. Analisis kelayakan usaha merupakan suatu analisis untuk mengetahui layak atau tidaknya usaha yang dijalankan dengan mengkaji beberapa aspek, yaitu aspek teknis, pasar, manajemen, dan aspek finansial (Rangkuti, 2012). Oleh karena itu, analisis kelayakan usaha sangat perlu dilakukan untuk mengetahui apakah usaha kerajinan tangan yang dijalankan layak atau tidak layak, guna mencapai tujuan yakni memperoleh keuntungan atau laba optimal dan mengevaluasi keberlanjutan usaha.

Penelitian mengenai kelayakan usaha telah banyak dilakukan di beberapa lokasi dengan obyek usaha yang berbeda (Kasmir \& Jakfar, 2010; Latuny, 2010; Palupi et al., 2016; Tangke, 2011; Thobias et al., 2013; Umar, 2003) namun kelayakan usaha kerajinan limbah sampah belum dilakukan. Hal tersebut menjadi dasar pertimbangan sehingga diperlukan kajian mengenai kelayakan finansial usaha kerajinan tangan/suvenir dari limbah oleh pelaku usaha, yaitu pemulung di Bantar Gebang.

Karakteristik mayoritas masyarakat Bantar Gebang berprofesi sebagai pemulung. Seperti terlihat pada foto, bahwa di tempat tersebut banyak sekali limbah sampah yang menjadi sandaran hidup bagi para pemulung mulai dari anak-anak, orang dewasa, hingga manula:
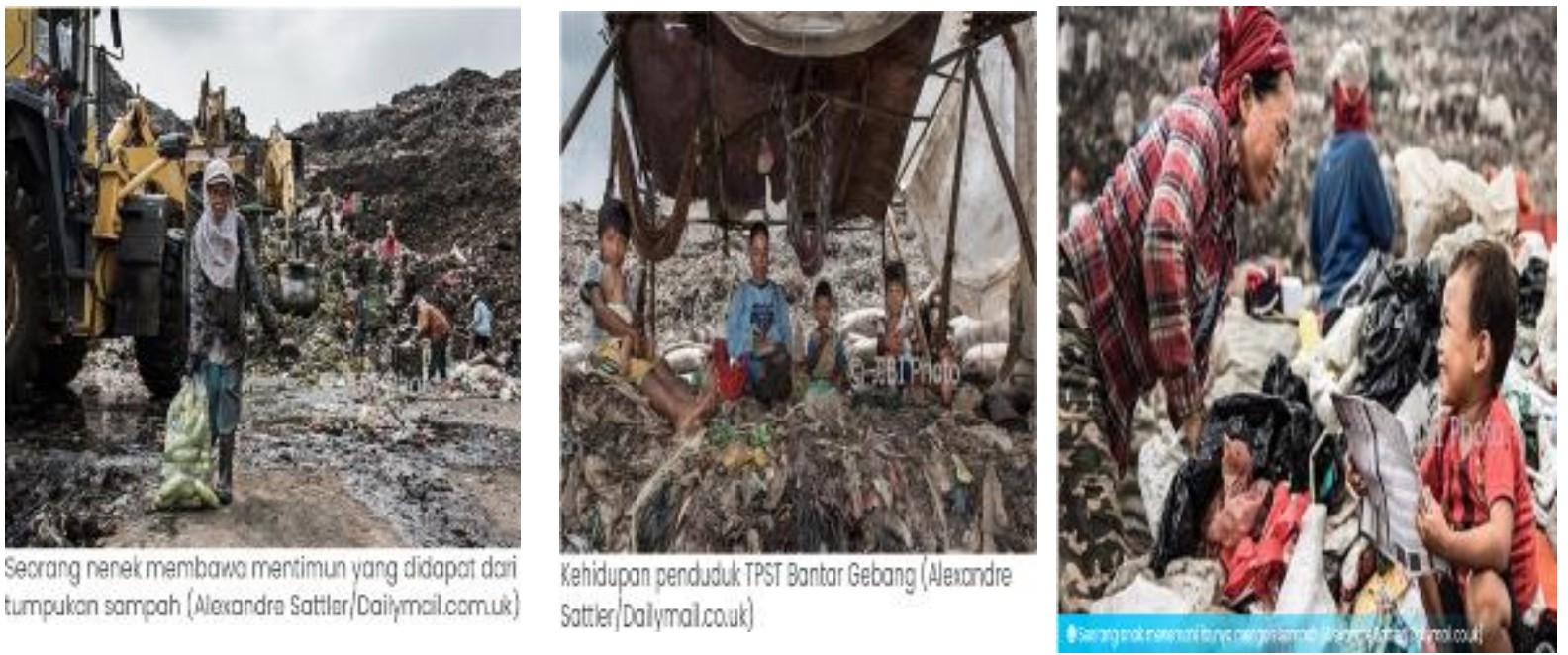

Gambar 2: Keadaan sampah pada TPST Bantar pada tahun 2017

Chelin Indra (Solopos.Com, 2017) 
Foto tersebut tidak berbeda jauh dengan kondisi kenyatan saat ini, berikut ini dokumentasi kami pada tahun 2020-2021:
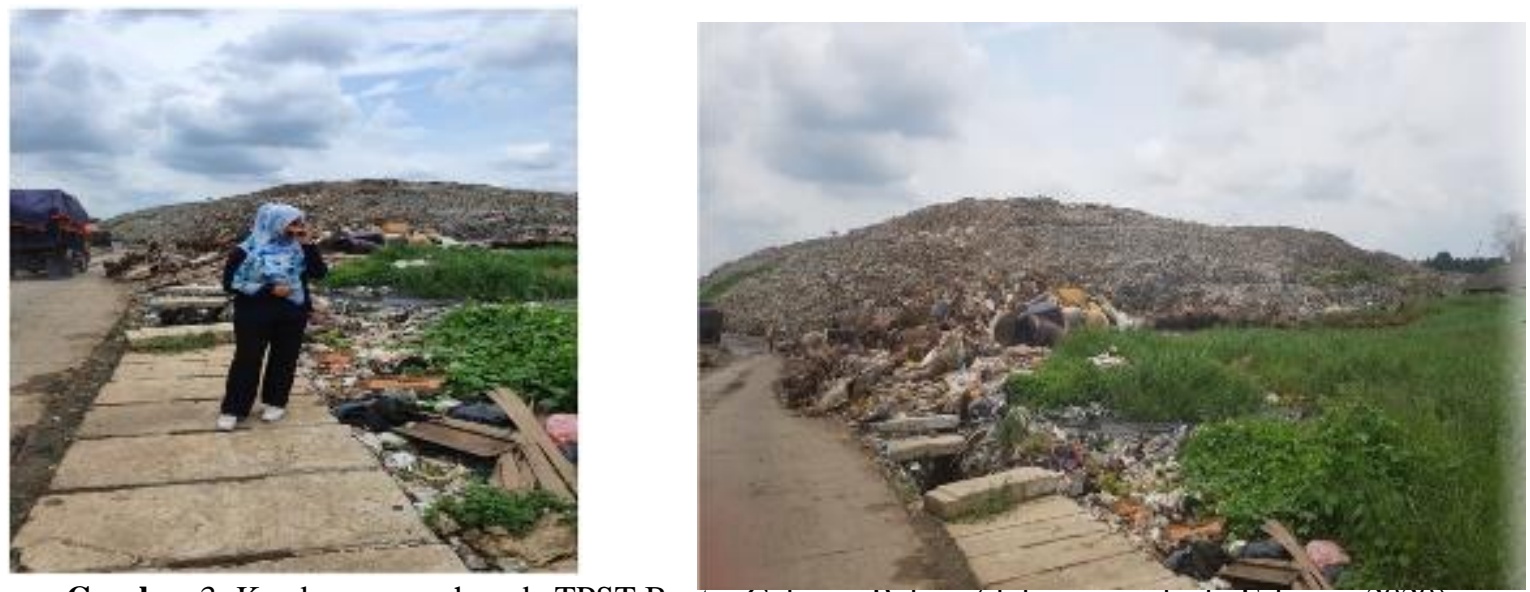

Gambar 3: Keadaan sampah pada TPST Bantar Gebang, Bekas1 (dokumen pribadi, Februarı 2020)

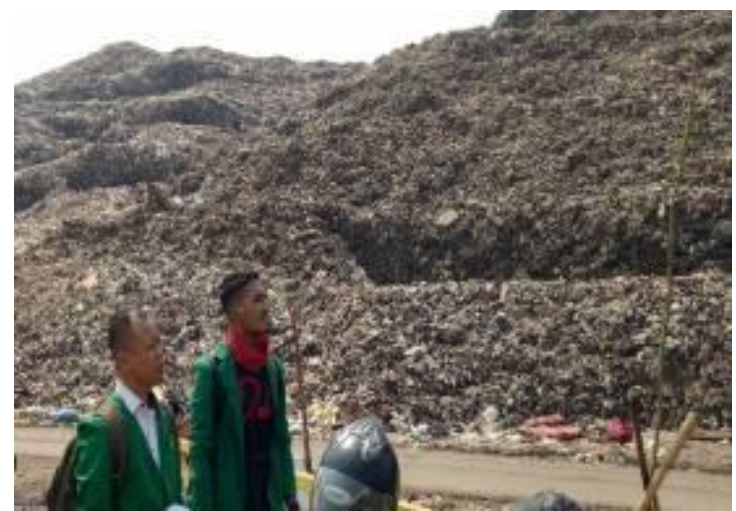

Gambar 4: Keadaan sampah pada TPST Bantar Gebang, Bekasi (dokumen pribadi, April 2021)

Berdasarkan pemantauan di lokasi terlihat masih ada sampah-sampah yang tampak baru di buang di tempat tersebut. Terlihat beberapa jenis sampah plastik, kain perca dan juga sisa barang bekas masih berada di atas permukaan tumpukan sampah. Sebanyak 2.000 ton limbah organik per hari sudah dimanfaatkan untuk kompos, sedangkan 4.500 ton limbah anorganik per hari belum ada pengelolaan khusus selain di daur ulang (recycle). Limbah anorganik adalah sisa limbah atau sampah yang sudah tidak dapat diuraikan kembali oleh Bakteri (dekomposer). Beberapa contoh limbah anorganik itu sendiri di antaranya adalah sisa sabun cuci, sampah kantong plastik, sisa kain yang sudah tidak digunakan, limbah hasil pabrik, limbah minyak, sampah botol plastik berbagai macam minuman, dan juga sampah yang berasal dari logam.

Pandemi virus corona membuat banyak orang mejerit dilanda kesulitan ekonomi. Terlebih bagi orang-orang yang mengais rupiah di jalan. Mereka dilema, berdiam diri di rumah tak bisa makan. Bekerja takut terjangkit virus corona. Kondisi inilah yang dialami oleh ribuan pemulung di Bantar Gebang, Kota Bekasi. Di tengah wabah, mereka setia menggantungkan hidup dari sampah. Selama pandemi Corona-19 harga sampah terus menurun. Ini berimbas pada pendapatan pemulung berkurang di atas 50\% (lima puluh persen), yang hanya mampu menghasilkan uang Rp.30.000,- hingga Rp.40.000.000,- per hari. Kondisi kian parah karena sejumlah pabrik daur ulang banyak yang tutup, 
sehingga sampah pungutan pemulung dibeli dengan harga semaunya. Saat ini harga sampah plastik hanya Rp.300,- per kilogram. Semenjak orang bekerja dari rumah, sampah menjadi sedikit, bahkan sampah hotel, mal, serta kantor hampir tidak ada. Pada masa pandemi corona, paling banyak hanya ada limbah plastik dan kardus (Felisiani, 2020).

Padahal dari limbah plastik dan kardus tersebut selain dijual ke pabrik daur ulang, juga dapat dimanfaatkan kembali menjadi berbagai macam kerajinan tangan, baik itu hiasan dinding, perlengkapan rumah tangga, aksesori dan lainnya yang berharga nilai jual lebih tinggi daripada di daur ulang (recycle). Hasil kerajinan tangan dengan sentuhan inovasi unik mampu memiliki nilai ekonomis yang "mahal". Melihat kondisi tersebut membuka peluang untuk mengadakan pemberdayaan masyarakat dalam memperbaiki ekonominya melalui pemanfaatan limbah sampah plastik dan kardus menjadi barang ekonomis yang bernilai jual tinggi.

Pengoptimalan usaha mikro limbah melalui pemberdayaan pemulung, dilakukan dengan menggunakan jejaring PKBM (Pusat Kegiatan Belajar Masyarakat) Al Falah Sumur Batu yang berlokasi di Kelurahan Sumur Batu, Kecamatan Bantar Gebang Kota Bekasi. Selain melihat peluang dengan mengoptimalkan limbah sampah, dan juga kegiatan PKM ini harus memanfaatkan jejaring organisasi PKBM (Pusat Kegiatan Belajar Masyarakat) Al Falah Sumur Batu yang telah terorganisir secara baik.

Tidak berkembangnya kewirausahaan pada kalangan pemulung, bukan semata disebabkan keengganan karena keterampilan yang kurang sesuai dengan kebutuhan dan peminatan mereka, namun juga karena: (1) kepada mereka belum ditransformasikan motivasi kewirausahaan; (2) karena di dalam mind-set mereka, bahwa hanya ada satu pekerjaan yang dapat mereka lakukan, yaitu sebagai pemulung, yang kesehariannya sangat bergantung pada pengumpulan limbah layak daur ulang. Dalam memenuhi kebutuhan hidup, masyarakat memiliki tingkat ketergantungan yang tinggi kepada tumpukan sampah. Bagi mereka, berwirausaha bukan jalan hidupnya, karena sangat beresiko dan membutuhkan modal besar.

Pelaksanaan kegiatan ini, memberikan pelatihan keterampilan sesuai peminatan mitra serta sumber daya alam yang dimilikinya, sehingga mitra mampu menghasilkan produk unggulan yang memiliki nilai ekonomis serta dibutuhkan oleh pasar. Untuk menghasilkan produk yang memiliki nilai jual, pelatihan keterampilan (1) pembuatan produk Ecobrics berbahan limbah plastik; dan (2) pelatihan keterampilan dari limbah kardus, yang diarahkan pada kualitas dan branding produk. Karena itu, pelatihan yang diberikan juga akan mencakup teknis produksi dan desain produk serta branding kemasan produk. Materi keterampilan pembuatan produk kerajinan tangan yang diajarkan antara lain membuat pot bunga, tempat asesoris, pajangan yang berbahan dasar limbah kardus dan plastik. Tak hanya itu, peserta juga diajarkan bagaimana mengemas produk kerajinan dengan teknik packaging yang dapat meningkatkan nilai jual, serta teknik pemasaran baik secara offline (langsung) maupun secara online berbasis Internet of Things (IoT), seperti memiliki Website sendiri serta bekerja sama melalui digital mulai dari Gojek, Grab, Tokopedia, Bukalapak, Shopee, Blibli, dan Lazada 
sehingga program yang dijalankan dapat terintegrasi dengan ekosistem digital agar hasilnya lebih terukur serta memiliki akses pasar yang lebih luas.

Pelatihan kewirausahaan ini memiliki tujuan sosial dan berbasis pada kegiatan sosial. Oleh sebab itu, kepada mitra akan diberikan pula pelatihan motivasi kewirausahaan dan keterampilan manajerial kewirausahaan, yang di dalamnya mencakup pula manajemen produksi, manajemen keuangan, akuntansi sederhana dan manajemen pemasaran. Selain itu, dilakukan pendampingan kepada mitra, agar upaya menumbuhkembangkan kegiatan usaha mikro pada para pemulung dapat terwujud dan berjalan dengan baik. Target luaran kegiatan pengabdian ini adalah dihasilkannya produk baru yang merupakan pengembangan varian produk usaha berupa: 1) barang rumah tangga ecobrics, pot bunga, tempat asesoris, pajangan, dll; 2) sistem manajemen usaha yang efektif yang meliputi pembukuan, laporan keuangan, personalia, 3) sistem pemasaran berbasis web dan 4) artikel ilmiah dalam jurnal. Karena khalayak sasaran dalam kegiatan ini adalah para pemulung, sehingga pengabdian ini bekerja sama dengan PKBM yang segala aktivitasnya sudah melembaga dalam kehidupan sehari-hari pemulung Kelurahan Sumur Batu, hal ini merupakan modal sosial yang di dalamnya terjalin: jejaring, kepercayaan, gotong royong dan nilai-nilai kehidupan lainnya. Pendayagunaan modal sosial tersebut dapat menjadi media pemberdayaan masyarakat dan penciptaan lapangan kerja (Thobias et al., 2013).

\section{METODE PELAKSANAAN}

Pelaksanaan pelatihan kewirausaha meliputi beberapa tahap yaitu: (a) tahap persiapan dan perencanaan, (b) tahap pelatihan pembuatan produk, (c) tahap pemberian motivasi dan pelatihan untuk mengembangkan skill manajerial, (d) tahap pelatihan pemasaran, dan (e) tahap pendempingan, monitoring dan evaluasi.

Tahap persiapan dan perencanaan dilakukan koordinasi dengan dengan LPPM STKIP Kusuma Negara. Tim pelaksana kegiatan dalam hal ini mempersiapkan alat dan bahan yang diperlukan untuk pembuatan aksesori, dan pemantauan kegiatan. Tahap pelatihan pembuatan produk, pada tahap ini peserta pelatihan diajarkan untuk membuat kerajinan dari bahan limbah kardus dan Pembuatan Produk Ecobrics Berbahan Limbah Plastik. Tahap Penyuluhan motivasi wirausaha dan pelatihan skill manajerial kewirausahaan, diarahkan untuk menumbuhkan motivasi peserta dalam berwirausaha dan kemampuan mengelola usaha. Tahap pelatihan pemasaran, disini peserta dilatih untuk pemanfaatan TIK (Internet of Thing) untuk pemasaran, diarahkan untuk menumbuhkan pengetahuan dan pemahaman kemudahan dalam pemasaran dengan menggunakan TIK. Tahap pendapingan, monitoring dan evaluasi, kegiatan dilakukan untuk memastikan peserta peserta dapat membuat produk dan memasarkannya dengan baik, serta memberikan alternatif solusi jika terjadi masalah. 


\section{HASIL DAN PEMBAHASAN}

Pelaksanaan pengabdian ini untuk mendukung upaya pengoptimalan usaha mikro pada pemulung. Target yang dicapai adalah: (1) tumbuh-kembangnya motivasi kewirausahaan; (2) tumbuhkembangnya keterampilan dan kegiatan para pemulung mitra yang mampu menghasilkan produk yang memiliki nilai ekonomis; (3) tumbuh-kembangnya keterampilan manajerial kewirausahaan dan pemasaran berbasis Internet of Things (IoT); (4) tumbuh-kembangnya kegiatan wirausaha para pemulung mitra, melalui pendampingan dan pembinaan dari kegiatan pengabdian.

Pelaksanaan pelatihan kewirausaha meliputi beberapa tahap yaitu: (a) tahap persiapan dan perencanaan, (b) tahap pelatihan pembuatan produk, (c) tahap pemberian motivasi dan pelatihan untuk mengembangkan skill manajerial, (d) tahap pelatihan pemasaran, dan (e) tahap pendempingan, monitoring dan evaluasi. Tahap persiapan dan perencanaan dilakukan koordinasi dengan dengan LPPM STKIP Kusuma Negara. Tim pelaksana kegiatan dalam hal ini mempersiapkan alat dan bahan yang diperlukan untuk pembuatan aksesori, dan pemantauan kegiatan.

Tahap pelatihan pembuatan produk, yang meliputi: (a) Memberikan penyuluhan tentang menghasilkan kreasi kerajinan tangan yang berkualitas yang mampu mengembangkan secara luas. (b) Memberikan inovasi kerajinan tangan yang ramah lingkungan untuk mendukung kebersihan dan kenyamanan lingkungan sekitar. (c) Memberikan penyuluhan menjadikan kerajinan tangan sebagai bisnis yang siap menghadapi pesaing pasar dengan kerajinan modern. (d) Memberikan penyuluhan menjadikan kerajinan sebagai bisnis dalam negeri dan bisa dijual sampai keluar negeri melalui pemasaran berbasis online. Pada tahap ini peserta pelatihan diajarkan untuk membuat kerajinan dari bahan limbah kardus dan Pembuatan Produk Ecobrics Berbahan Limbah Plastik.

Pembuatan produk dari bahan limbah kardus yang didahului dengan perencanaan disain produk, membuat pola sesuai dengan ukuran dan disain produk, mengkombinasikan bahan baku dengan bahan dekoratif lainnya sesuai dengan desain. Setelah itu, kardus dibentuk berbagai jenis bunga, daun dan bentuk lainnya, maka seluruhnya disusun sehingga menjadi produk pajangan, dan juga mengemas produk.

Diarahkan untuk menciptakan produk yang memiliki nilai jual tinggi dan sebagai produk unggulan mitra, pelatihan ini akan mencakup: (a) Pelatihan desain produk, (b) Pelatihan pembuatan produk, dan Branding kemasan produk, (c) Pelatihan pemasaran online berbasis Internet of Things (IoT). 

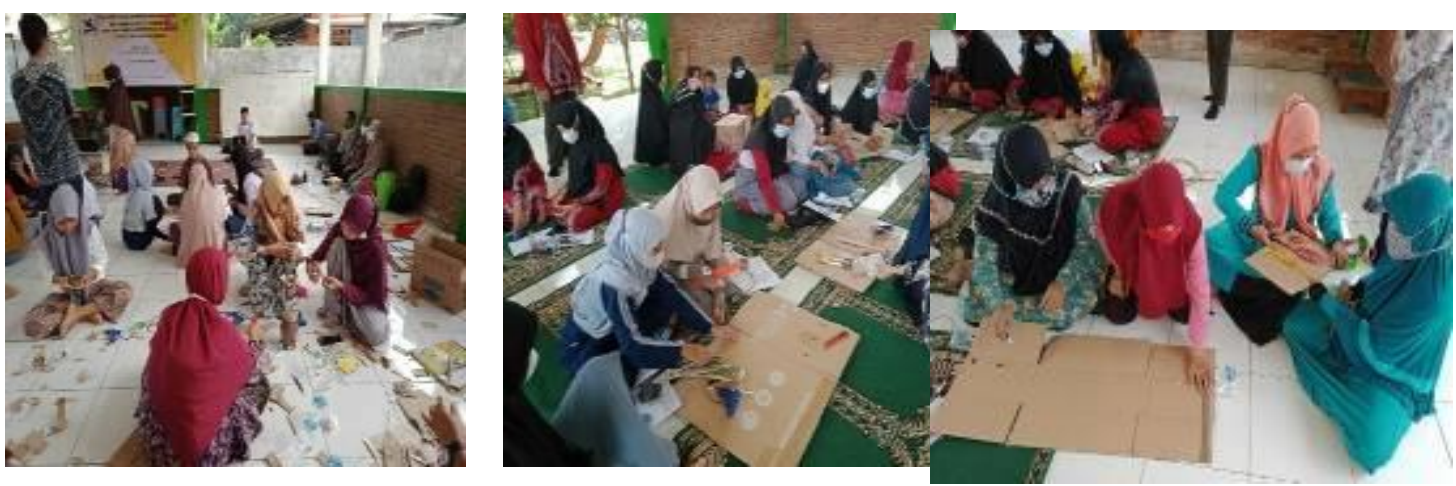

Gambar 5: Pelatihan Kerajinan Limbah Kardus, Bantar Gebang, Bekasi (dokumen pribadi, 2021)

\section{Contoh-contoh Hasil Kerajinan Limbah Kardus :}

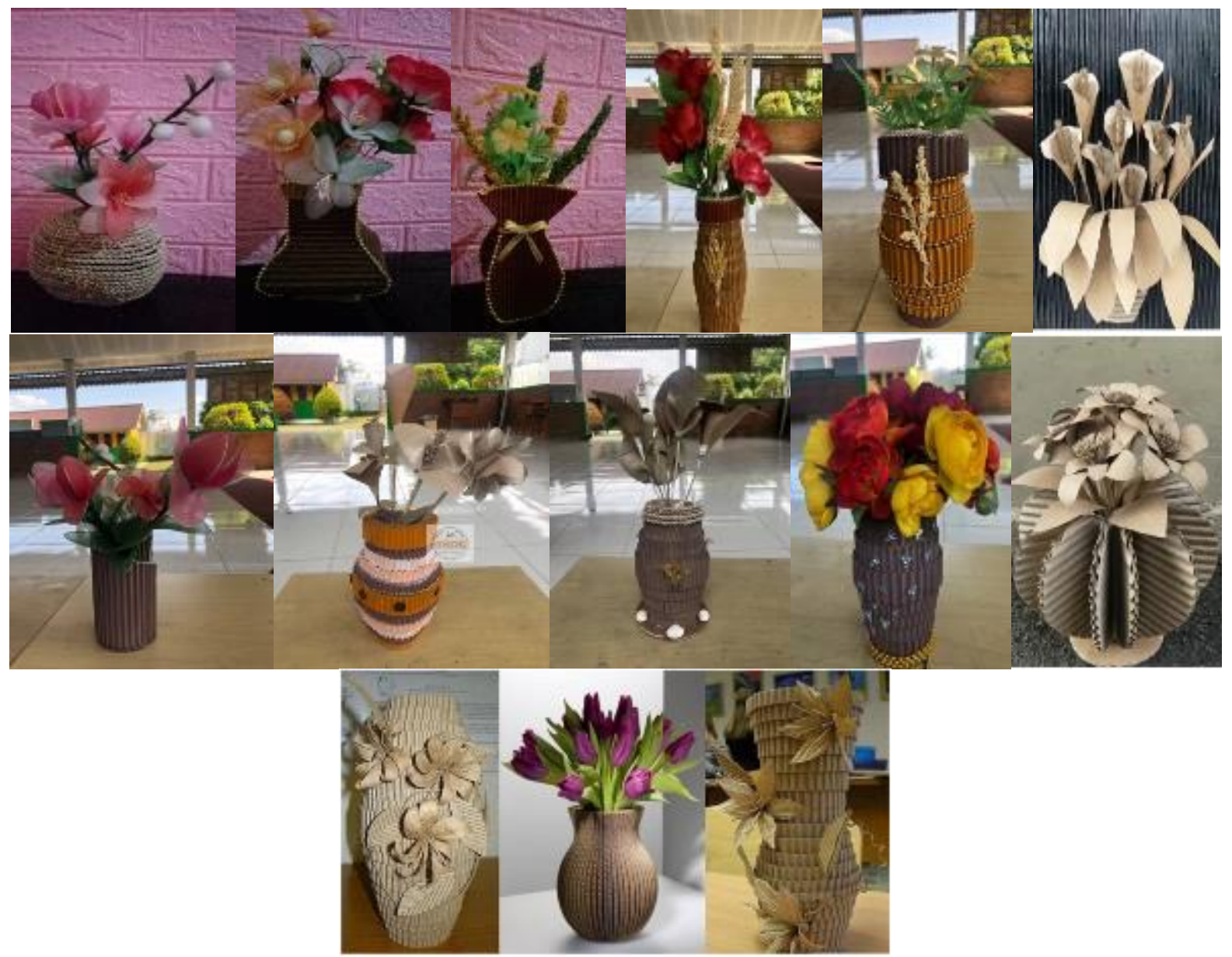

Ecobrics merupakan bata ramah lingkungan. Ecobrics dianggap sebagai salah satu cara pemanfaatan limbah plastik yang mudah dan efisien. 

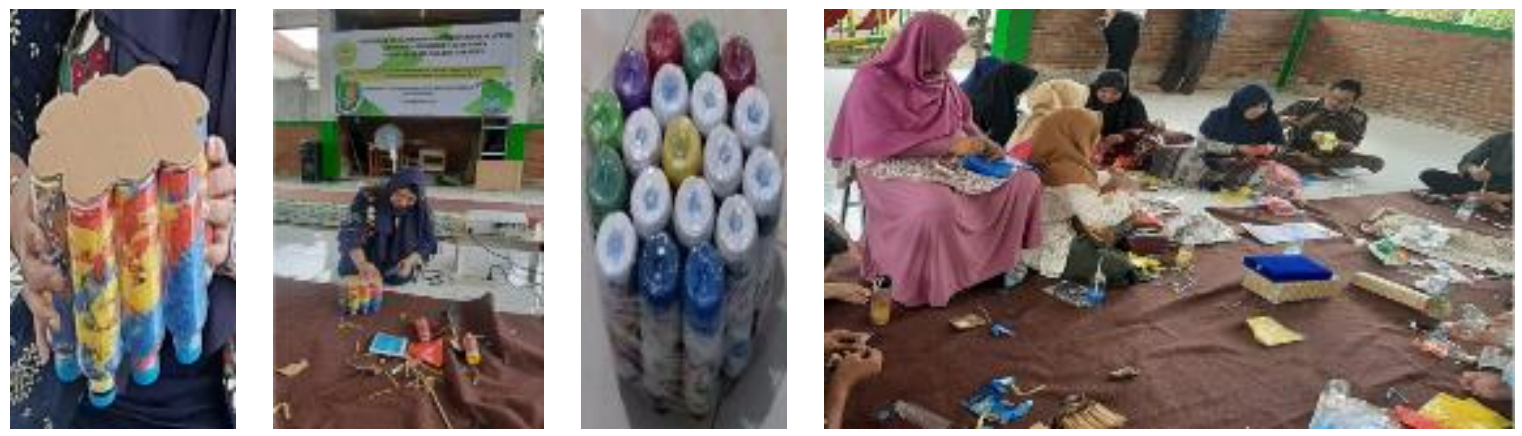

Gambar 6: Pelatihan Kerajinan Limbah Kardus, Bantar Gebang, Bekasi (dokumen pribadi, 2021)

\section{Contoh Produk Ecobrics berbahan limbah plastik:}
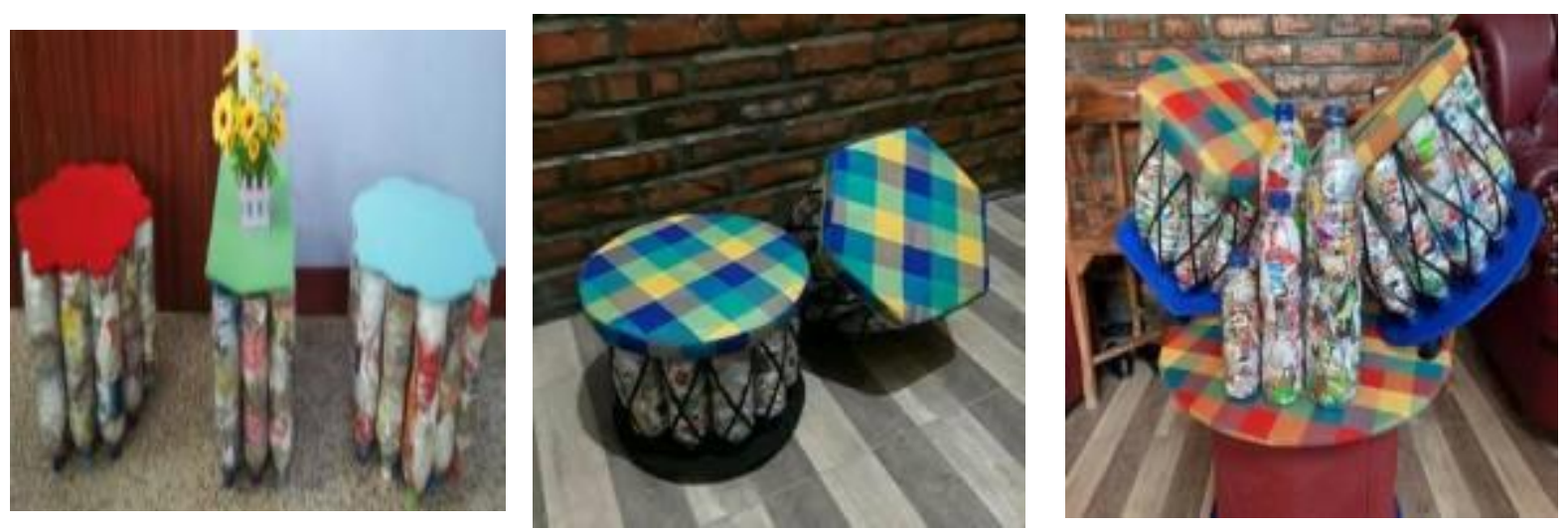

Penyuluhan motivasi wirausaha dan pelatihan skill manajerial kewirausahaan, diarahkan untuk menumbuhkan motivasi peserta dalam berwirausaha dan kemampuan mengelola usaha, yang meliputi: a) penyuluhan motivasi usaha; b) pengenalan usaha mikro; c) pelatihan pembuatan perencanaan usaha; d) pelatihan manajemen operasi dan produksi; e) pelatihan manajemen pemasaran; dan f) pelatihan manajemen keuangan dan akuntansi sederhana.

Pada pelatihan manajerial, para pemulung memperoleh manfaat mampu melakukan analisis perhitungan BEP untuk mengetahui gambaran kondisi produksi yang harus dicapai untuk melampaui titik impas. Kegiatan wirausaha dikatakan impas jika jumlah hasil penjualan produknya pada suatu periode tertentu sama dengan jumlah biaya yang ditanggung sehingga usaha tersebut tidak menderita kerugian, tetapi juga tidak memperoleh laba. Analisis titik impas dapat disebut Break Event Point (BEP) dimana dapat diperhitungkan batas kuantitas produksi yang mengalami keuntungan dan kerugian pada usaha yang dilakukan oleh pemulung. Analisis kelayakan usaha atau disebut juga feasibility study adalah kegiatan untuk menilai sejauh mana manfaat yang dapat diperoleh dalam melaksanakan suatu kegiatan usaha. Hasil analisis ini digunakan sebagai bahan pertimbangan dalam mengambil keputusan, apakah menerima atau menolak dari suatu gagasan usaha. Pengertian layak dalam penelitan ini adalah kemungkinan dari gagasan suatu usaha yang akan dilaksanakan dapat memberikan manfaat dalam arti finansial maupun social benefit. Dengan adanya analisis kelayakan diharapkan resiko kegagalan dalam usaha produktif dapat dihindari (Kasmir \& Jakfar, 2010). 
Pelatihan pemanfaatan TIK (Internet of Thing) untuk pemasaran, diarahkan untuk menumbuhkan pengetahuan dan pemahaman kemudahan dalam pemasaran dengan menggunakan TIK, yang mencakup: a) Pengenalan TIK dan jejaring media sosial internet; b) Pembuatan blog; c) Pemanfaatan TIK untuk pemasaran secara online; d) Transaksi dalam pemasaran online.

Tahap pendapingan, monitoring dan evaluasi, kegiatan pendampingan dilakukan dalam rangka menambah pengetahuan: (a) Pemahaman dan aplikasi pengetahuan dan skill manajerial. (b) Analisis potensi pasar dan pembuatan perencanaan usaha dan agar aplikatif. (c) Merancang /membangun dan mengelola usaha bersama dalam bentuk usaha mikro melalui kegiatan PKBM (mulai dari perencanaan, proses produksi, pemasaran, pengaturan mekanisme dan sistem pembagian keuntungan usaha). Pada tahap monitoring dan evaluasi, dikethui bahwa ada beberapa dari peserta pelatihan yang mengalami kendala pada saat pemasaran secara online. Solusi yang dilakukan yaitu dengan mendapingi peserta secara pertahap untuk dapat malakukan pemasaran secara online secara mandiri dan dibuat web yang digunakan untuk melakukan pemasaran produk secara kolektif dari semua peserta pelatihan.

\section{KESIMPULAN}

Pelatihan kewirausahaan bertujuan untuk memberikan pelatihan kepada masyarakat yang ada di sekitar TPST Bantar Gebang yang sebagian besar berprofesi sebagai pemulung. Para peserta pelatihan diajarkan mengelola sampah untuk diubah menjadi barang yang lebih bernilai guna dan ekomoni. Setelah proses pelatihan para dapat mengolah sampah untuk dibuat menjadi barang rumah tangga ecobrics, pot bunga, tempat asesoris, pajangan, dll. Selain menghasilkan produk, para peserta pelatihan juga membuat laporan keuangan secara sederhana dan mulai memasarkan produk secara online. Setelah proses pelatihan dilakukan proses pendampingan, monitoring, dan evaluasi. Berdasarkan hasil monitoring dan evaluasi ada beberapa peserta pelatihan yang masih terkendala saat melakukan pemasaran secara online. Solusi yang diberikan yaitu dengan melakukan pendapingan dan mambuat web untuk memasarkan produk bersama.

\section{UCAPAN TERIMA KASIH}

Ucapan terima kasih kepada Kementerian Riset dan Teknologi-Badan Riset Inovasi (RISTEKBRIN) dan LLDIKTI Wilayah III Jakarta yang telah mensponsori kegiatan pengabdian kepada masyarakat, dan kami haturkan ucapan terimakasih kepada Ketua STKIP Kusuma Negara, Kaprodi PPKN STKIP Kusuma Negara, Kepala Sekolah PKBM Al-Falah Sumur Batu, Ketua RT.002/RW.001 Kelurahan Sumur Batu Kecamatan Bantar Gebang, serta semua pihak yang berperan sehingga terlaksana kegiatan PKM pendampingan dan penyuluhan kerajinan limbah kreatif pada pemulung di TPA Bantar Gebang Bekasi, sehingga dapat dituangkan dalam bentuk artikel. 


\section{DAFTAR PUSTAKA}

Andriani, D. (2020, September 8). UMKM didorong adaptasi di masa pandemi, go digital! Bisnis.Com. https://ekonomi.bisnis.com/read/20200908/12/1288568/umkm-didorong-adaptasidi-masa-pandemi-go-digital

Farhanah. (2020, September 9). UMKM terdampak pandemi, pemerintah dan swasta gotong royong dorong pertumbuhan ekonomi. Kompas.Com. https://money.kompas.com/read/2020/09/09/143611226/umkm-terdampak-pandemi-pemerintahdan-swasta-gotong-royong-dorong-pertumbuhan

Felisiani, T. (2020, May 18). Kerasnya hidup pemulung Bantar Gebang menghadapi virus Corona. Tribunnews.Com. https://www.tribunnews.com/metropolitan/2020/05/18/kerasnya-hiduppemulung-bantar-gebang-menghadapi-virus-corona

Kasmir, \& Jakfar. (2010). Studi kelayakan bisnis. Kencana Prenada Media Group.

Latuny, W. (2010). Analisis kelayakan aspek finansial industri kerajinan kerang mutiara. Arika, 04(1), 89-96.

Palupi, R. D., Ira, \& Asriyana. (2016). Strategi pengembangan usaha wanita nelayan dalam mengolah hasil perikanan berbasis kelompok. Jurnal Bisnis Perikanan, 3(2), 137-144. http://ojs.uho.ac.id/index.php/bisnisperikanan/article/view/2232/1600

Rangkuti, F. (2012). Studi kelayakan bisnis dan investasi. Gramedia Pustaka Utama.

Soleha, A. R. (2020). Kondisi UMKM masa pandemi Covid-19 pada pertumbuhan ekonomi krisis serta program pemulihan ekonomi nasional. Jurnal Ekombis, 6(2), 165-178. http://jurnal.utu.ac.id/ekombis/article/view/2881/1804

Tangke, U. (2011). Analisis kelayakan usaha perikanan tangkap menggunakan alat tangkap gill net dan purse seine di Kecamatan Leihitu Kabupaten Maluku Tengah Provinsi Maluku. Agrikan: Jurnal Agribisnis Perikanan, 4(1), 1-13. https://doi.org/10.29239/j.agrikan.4.1.1-13

Thobias, E., Tungka, A. K., \& Rogahang, J. J. (2013). Pengaruh modal sosial terhadap perilaku kewirausahaan (Suatu studi pada pelaku usaha mikro kecil menengah di Kecamatan Kabaruan Kabupaten Kepulauan Talaud). Acta Diurna, April, 1-13.

Umar, H. (2003). Studi kelayakan dalam bisnis jasa. Gramedia Pustaka Utama.

Utami, P. P., Vioreza, N., Nugraheny, D. C., Putri, A., \& Arihati, D. B. (2019). PKM kelompok UMKM kerajinan tangan unik laut. Jurnal Abadimas Adi Buana, 03(1), 49-56. https://doi.org/10.36456/abadimas.v3.i1.a1944 